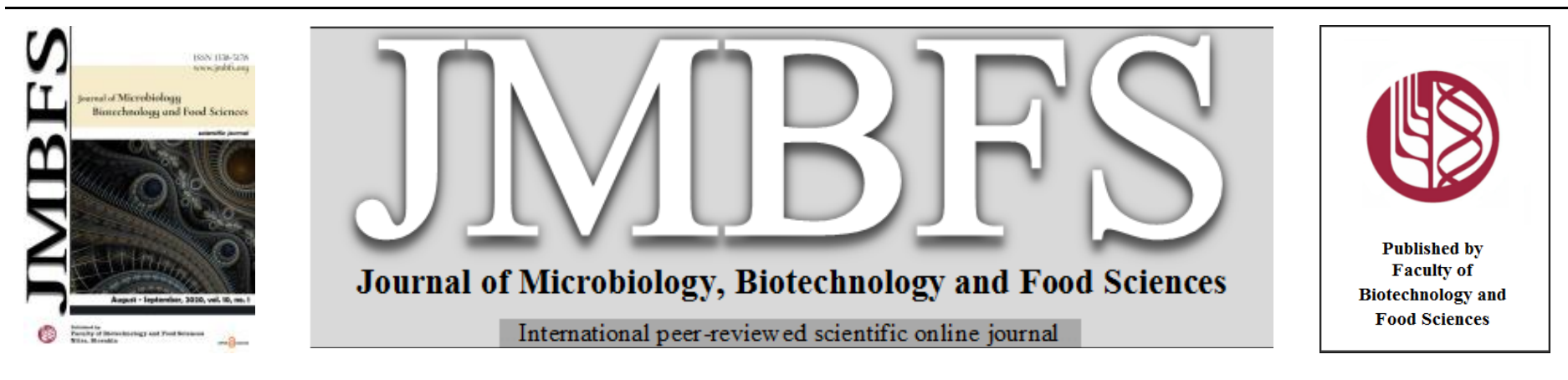

\title{
SUPPLEMENTAL METHIONINE, CHOLINE, OR TAURINE AFFECT GALECTIN GENE EXPRESSION IN ADULT HOLSTEIN COW AND NEONATAL HOLSTEIN CALF NEUTROPHILS IN VITRO
}

\author{
Emmanuel K. Asiamah $*^{1}$, Mario Vailati-Riboni ${ }^{2}$, Juan J. Loor ${ }^{2}$, Mulumebet Work ${ }^{3} *$, Hye won Kang ${ }^{4}$
}

Address(es): Dr. Mulumebet Worku,

${ }^{1}$ Department of Agriculture, University of Arkansas at Pine Bluff, 1200 N University Drive, Pine Bluff, AR, 71603, USA, (870)-575-8981.

${ }^{2}$ Department of Animal Sciences, University of Illinois, 1207 West Gregory Drive, Urbana, 61801, USA. (217)-244-5957.

${ }^{3}$ Department of Animal Sciences, North Carolina A\&T State University, 1601 E Market Street, Greensboro, NC, 27411 US, (336)-285-4816.

${ }^{4}$ Department of Family and Consumer Sciences, North Carolina A\&T State University, 1601 E Market Street, Greensboro, NC, 27411 US, (336)-285-4858.

*Corresponding author: worku@ncat.edu

doi: $10.15414 / j m b f s .2020 .10 .1 .87-92$

ARTICLE INFO

Received 14. 11. 2018

Revised 13. 3. 2020

Accepted 23. 3. 2020

Published 1. 8. 2020

Regular article

open $\partial$ ACCESS

\begin{abstract}
The aim of the study was to evaluate the effect of methyl donor supplementation on mRNA expression of galectin genes in cow and calf neutrophils in vitro. Galectins play a crucial role in homeostasis and disease regulation. Ten adult Holstein cows and five neonatal Holstein calves ( $3 \mathrm{wk}$. old) were used for isolation and in vitro culture of neutrophils. Neutrophils isolated from the adult cows were divided into two groups. Neutrophils from Group 1 were incubated with three concentrations of Lysine (Lys) to Met ratios of (3.6:1, 2.9:1, or 2.4:1). Neutrophils from Group 2 were also incubated with three concentrations of Lys to Met ratios and $50 \mu \mathrm{g} / \mathrm{mL}$ of LPS. Isolated neutrophils from calves were incubated with Met, Choline, and Taurine $\left(37{ }^{\circ} \mathrm{C}\right.$, with $5 \% \mathrm{CO}_{2}$ or 4 hours). Met did not affect $L G A L S$ expression in Group 1 cows.

In Group 2, however, relative mRNA expression of LGALS9 was higher in neutrophils treated with 3.6 Lys: Met and 2.9 Lys: Met concentrations compared to 2.4 Lys: Met $(0.33,0.36$ and 0.16 respectively) $(\mathrm{P}<0.05)$. A Met X LPS interaction was also observed in regard to the expression of LGALS8. LGALS8 transcription decreased when neutrophils were treated with LPS at 3.6 Lys: Met (No LPS $=0.89$ LPS $=0.56)(\mathrm{P}<0.05)$. On the contrary, LGALS8 expression increased at 2.9 Lys: Met in the presence of LPS (No LPS $=0.52$ LPS $=1.95)(\mathrm{P}<0.05)$. Treatment with LPS alone increased the expression of LGALS4 $(\mathrm{P}<0.05)$ and tended to increase LGALS12 $(\mathrm{P}<0.10)$ compared to control.

In calves, $L G A L S-2,-7$, and -9 were undetected. $L G A L S-1,-3,-4,-8$, and -12 were all reduced in neutrophils treated with 2.4 and 2.6 Lys: Met compared to 3.6 Lys: Met. Increasing Choline concentration tended to reduce LGALS1 ( $\mathrm{P}<0.05)$ but reduced LGALS8 $(\mathrm{P}<0.05)$. Increasing taurine reduced $L G A L S 1$ and tended to reduce LGALS12. These results shed light on the modulation of galectin expression in cow and calf neutrophils in response to methyl donors.
\end{abstract}

Keywords: Neutrophils, Galectins, Cows, Calves, Methionine, Choline, Taurine

\section{INTRODUCTION}

An animal with a properly functioning immune system is protected from a variety of pathogenic organisms, including viruses, bacteria, and parasites (Kawai and Akira 2010). The immune mechanisms of the animal rely tightly on the effective elimination of injurious insults and the return of tissues to homeostasis (Sordillo, Contreras et al. 2009). Adult dairy cows during the periparturient period, as well as neonatal calves, have been shown to be more susceptible to infectious diseases (Asiamah, Ekwemalor et al. 2019, Asiamah, Vailati-Riboni et al. 2019). The dysfunction of the bovine immune response is the major contributing factor to the increased health disorders in the periparturient cow (Sordillo, Contreras et al. 2009). Infectious diseases, like bovine mastitis in cows,enteritis, diarrhea, septicemia, and pneumonia in calves are major economic setbacks in the dairy industry. Because of this, numerous studies focused on elucidating the molecular mechanisms leading to metabolic and infectious diseases are emerging(Adjei-Fremah, Ekwemalor et al. 2016, Adjei-Fremah, Jackai et al. 2016, Asiamah, Adjei-Fremah et al. 2016, Asiamah, Adjei-Fremah et al. 2016). Our understanding of this phenomenon will lead to the design of effective management practices in order to reduce cow and calf health disorders. Supplementation with methyl donors (e.g. methionine, or choline) to dairy cows is useful in the optimization of dry matter intake (DMI), milk production, and improvement of the phagocytotic capacity of blood (Li, Batistel et al. 2016). In non-ruminants, Met and its derivate metabolites (e.g., glutathione, polyamines, and taurine) are well-known immunonutrients that support and boost immune functions and activities.

An effective immune response depends to an extent on how efficient neutrophils are activated upon pathogenic attack (Rosen, Klebanoff et al. 2009). Neutrophils are the first line of defense against infectious agents and are involved in inflammatory processes. They account for about $25 \%$ of the leukocytes in bovine peripheral blood of healthy animals (Sander, Piechotta et al. 2011). Inflammatory stimuli promotes neutrophil accumulation at inflammation sites, and recent studies have shown that cell adhesion molecules like galectins play an essential role in many of the events involved in the neutrophil recruitment and migration into extravascular spaces (Kehrli, Nonnecke et al. 1989, Almkvist and Karlsson 2002, Nishi, Shoji et al. 2003, Schorn, Janko et al. 2012). Galectins, a group of evolutionarily conserved proteins that bind to $\beta$-galactosides have been known to be associated with immune regulation via neutrophil recruitment and migration and hence plays a dual modulation role in cell adhesion and immune/inflammatory processes (Almkvist and Karlsson 2002, Nishi, Shoji et al. 2003). Galectins are important modulators of several biological functions and have been implicated in numerous disease conditions (Almkvist and Karlsson 2002, Liu and Rabinovich 2005, Sato, St-Pierre et al. 2009, Cooper, Iqbal et al. 2012, Rabinovich, van Kooyk et al. 2012).

Because galectin expression is closely linked to immune-modulation and inflammation (Ekwemalor, Asiamah et al. 2017, Asiamah, Adjei-Fremah et al. 2018), it is imperative to explore whether galectin gene expression in neutrophils is affected with Met supplementation in cows and calves. Thus, we hypothesized that supplementation with methionine, taurine, or choline would benefit the innate immune response of cows and calves at least in part by altering the expression of galectin genes associated with neutrophils activity and inflammation. Therefore, the objective of the study was to evaluate the effect of methyl donor supplementation on mRNA expression of galectin genes in cow and calf neutrophils in vitro.

To test our hypothesis, neutrophils from mid-lactating pluriparous Holstein cows were used to determine neutrophils' inflammatory response to an LPS challenge and Met stimuli. The effect of Met, $\mathrm{CHO}$, and TAU supplementation in vitro on the mRNA expression of galectin genes in neutrophils isolated from neonata calves was also determined. 


\section{MATERIAL AND METHODS}

\section{Animal handling}

Both cows and calves used for the study were part of the main herd of the University of Illinois Urbana Champaign. Details of the experimental design have been described previously (Abdelmegeid, Vailati-Riboni et al. 2017). Before blood collection, calves were fed and managed according to established standard operating procedures. The calves wed fed their first-milk colostrum within 2 hrs after birth. Calves were housed in individual outdoor hutches bedded with straw. A milk replacer (Advance Excelerate, Milk Specialties, Carpentersville, IL; $28.5 \%$ CP, $15 \%$ fat; supplemented with 1-Lys and dl-Met) was fed to the calves two times daily $(0700$ and $1800 \mathrm{~h})$. Calves also had free access to a starter grain mix $(19.9 \% \mathrm{CP}, 13.5 \% \mathrm{NDF})$ at $0800 \mathrm{~h}$ ad libitum. Calves were fed $2.27 \mathrm{~kg}(5.0 \mathrm{lb})$ of milk replacer at each feeding until $10 \mathrm{~d}$ of age and were then switched to $2.95 \mathrm{~kg}(6.5 \mathrm{lb})$ until the time of sampling $(3 \mathrm{wk}$ of age). Animals did not have any recorded health problems at sampling time.

\section{Blood sample collection.}

Details of the blood sampling have been described previously (Zhou, Bulgari et al. 2016, Abdelmegeid, Vailati-Riboni et al. 2017). Briefly,whole blood was aseptically collected from the coccygeal vein of ten mid-lactating pluriparous Holstein cows (First group of cows $n=5(238 \pm 20$ DIM, $33.8 \pm 3.9 \mathrm{~kg} / \mathrm{d}$ average milk production) and the second group of cows $n=5(153 \pm 5$ DIM, $34.6 \pm 2.7$ $\mathrm{kg} / \mathrm{d}$ average milk production), and the jugular vein of $3 \mathrm{wk}$ old calves into $10 \mathrm{~mL}$ vacutainer tubes containing a solution of trisodium citrate, citric acid and dextrose (ACD) and lithium heparin (10 mL, BD Vacutainer, Becton Dickinson). Tubes were inverted ten times, placed on ice, and immediately transported to the Mammalian NutriPhysioGenomics laboratory for neutrophils isolation. Isolation was done within an hour after isolation. No more than 40 min passed from the beginning of sampling to start of isolation.

\section{Neutrophils isolation and viability analysis.}

The neutrophils were isolated using a previously described protocol(Jacometo, Zhou et al. 2016). Briefly, samples were centrifuged to separate the phases, then plasma, buffy coat, and approximately one-third of the red blood cells were removed and discarded. The remaining material was combined, and red blood cells were lysed using deionized water at $4{ }^{\circ} \mathrm{C}$, followed by addition of $5 \times$ PBS at $4{ }^{\circ} \mathrm{C}$ to restore isotonicity. Cells were pelleted by centrifugation, and the supernatant was discarded. The pellet was then washed with $1 \times$ PBS and a second lysis step with deionized water was performed. After repelleting, 2 subsequent washings using $1 \times \mathrm{PBS}$ at $4{ }^{\circ} \mathrm{C}$ were performed. The resulting neutrophil pellets from the five animals were then mixed to obtain a homogeneous pool, and washed again with $1 \times$ PBS. Before incubation, to assess purity and viability, an aliquot was stained with the granulocyte antibody CH138A, followed by a second antibody (phycoerythrin), and propidium iodide, before the reading with a flow cytometer. The neutrophil pool had a purity greater than $80 \%$ and viability greater than $80 \%$.

\section{Neutrophils incubation and treatments.}

Cells from the isolated pool of neutrophils were counted using an automated cell counter (MOXI Z Mini, Or-flo Technologies) and diluted to a final concentration of $6 \times 106$ cells $/ \mathrm{mL}$ with warm $\left(37^{\circ} \mathrm{C}\right)$, Met-free incubation medium (RPMI 1640, Gibco, Thermo Fisher) and $8 \%$ fetal bovine serum (Sigma-Aldrich), previously heat-inactivated. From the diluted pool, aliquots of $1 \mathrm{~mL}$ were incubated in 14-mL endotoxin-free tubes (Thermo Fisher Scientific) with a snap cap designed to allow airflow, and allocated to each experimental group. The neutrophils were incubated at (1)3 different Lys to Met ratios (3.6:1, 2.9:1, or 2.4:1), calculated on the basis of the concentration of Lys in the medium; (2) 3 levels of supplemental $\mathrm{CHO}(0,400$, or $800 \mu \mathrm{g} / \mathrm{mL})$ over the basal level of $\mathrm{CHO}$ already in the medium $(3 \mu \mathrm{g} / \mathrm{mL}$, as choline chloride), with a Lys: Met (L: M) of $3.6: 1$; or (3) 3 levels of supplemental TAU $(0,4$, or $8 \mu \mathrm{g} / \mathrm{mL})$, with an L: M of 3.6:1. To obtain these groups, the calculated amounts of Met (as 1-Met; SigmaAldrich), CHO (as choline chloride; Sigma-Aldrich), and TAU (as taurine; Sigma-Aldrich) were added to test tubes from stock solutions previously prepared using the incubation medium as a diluent. Incubation lasted $4 \mathrm{~h}$ at $37^{\circ} \mathrm{C}$ in a sterile incubator, with a controlled atmospheric level of $\mathrm{CO} 2(5 \%)$. Tubes were gently shaken to mix and resuspend the cells every $20 \mathrm{~min}$.

\section{Stimulation of neutrophils with LPS}

LPS (Escherichia coli O111: B4, Sigma-Aldrich, St. Louis, MO) was prepared by dilution in Dulbecco's modified Eagle medium (Sigma-Aldrich) to obtain 50 $\mu \mathrm{g}$ of LPS $/ \mathrm{mL}$. The solution was aliquoted, to avoid multiple thawing and freezing, and stored at $-20{ }^{\circ} \mathrm{C}$ until use. Three aliquots of $980 \mu \mathrm{L}$ of blood from each cow were stimulated, in duplicate, under a laminar airflow cabinet with $20 \mu \mathrm{L}$ of Dulbecco's modified Eagle medium (negative control sample), solutions containing $50 \mu \mathrm{g}$ of LPS $/ \mathrm{mL}$. Samples were then incubated in a water bath at 38 ${ }^{\circ} \mathrm{C}$ for $3.5 \mathrm{~h}$ with a horizontal shaking speed of 30 times/min. After incubation, plasma was harvested by centrifugation $\left(8,700 \times \mathrm{g}\right.$ for $16 \mathrm{~min}$ at $\left.6^{\circ} \mathrm{C}\right)$ and stored at $-80{ }^{\circ} \mathrm{C}$. Environmental contamination with exogenous endotoxins was prevented by using certified endotoxin-free materials.

\section{RNA extraction and cDNA synthesis.}

The complete details of the procedures used have been previously reported (Asiamah, Vailati-Riboni et al. 2019). Briefly, Qiazol was used to extract RNA from isolated neutrophils according to manufacturer's protocol(Qiagen Corp). A NanoDrop ND-1000 spectrophotometer (NanoDrop Technologies) and a 2100 Bioanalyzer(Agilent Technologies) were used to assess RNA concentration and RNA integrity respectively. Extracted RNA samples with purity(A260/A280) of 1.9 and above were used for cDNA synthesis, using established protocols in the Mammalian NutriPhysioGenomics Laboratory (Riboni, Meier et al. 2015). A SYBR Green-based real-time quantitative PCR was performed using a 7-point standard curve.

\section{Gene expression Profiling.}

Primers used for qPCR are shown in Table 1 below. Primer3 Input (version 0.4.0) online tool was used to design the primers. Primer sequences were aligned against the NCBI online database using BLASTN. The qPCR primers were tested in a $20 \mu \mathrm{L}$ PCR reaction before qPCR was performed. The protocol used was the same as described by Vailati et al., 2017 for qPCR except for the final dissociation protocol. A universal reference gene was used to test the primers to ensure that the desired genes were identified. Primer testing procedure has been reported in detail elsewhere (Vailati-Riboni, Zhou et al. 2017).

Table 1 Primers used for real-time qPCR

\begin{tabular}{|c|c|c|c|}
\hline Gene & Primer & Sequence $5^{\prime}>3^{\prime}$ & $\begin{array}{c}\text { Product Size } \\
(b p)\end{array}$ \\
\hline \multirow{2}{*}{$L G A L S 1$} & Forward & GGCAAAGACGACAACAACC & \multirow{2}{*}{189} \\
\hline & Reverse & ТGGTTAGGTCCGTCTGGTTGA & \\
\hline \multirow{2}{*}{$L G A L S 2$} & Forward & CCTCACCAGAGAGCAAGACC & \multirow{2}{*}{181} \\
\hline & Reverse & TGGAAAACACCACAGTTGGA & \\
\hline \multirow{2}{*}{$L G A L S 3$} & Forward & GAATGATGTCGCCTTCCACT & \multirow[t]{2}{*}{165} \\
\hline & Reverse & TCAGGTTCAACCAGCACTTG & \\
\hline \multirow{2}{*}{ LGALS4 } & Forward & ATTCACGACTCCTGCAGCTT & \multirow{2}{*}{215} \\
\hline & Reverse & ССССАССТCGAAGTTTACAA & \\
\hline \multirow{2}{*}{$L G A L S 7$} & Forward & TCTACGTGAACCTGCTGTGC & \multirow{2}{*}{236} \\
\hline & Reverse & CCGGAAGTGGTGGTACTCAG & \\
\hline \multirow{2}{*}{$L G A L S 8$} & Forward & TCGTGATCATGGTCCTGAAA & \multirow{2}{*}{232} \\
\hline & Reverse & TGTGACTCGCCAGACTTTTG & \\
\hline \multirow{2}{*}{$L G A L S 9$} & Forward & TGTACCCCTCCAAGAGCATC & \multirow{2}{*}{233} \\
\hline & Reverse & ACACATGATCCACACCGAGA & \\
\hline \multirow{2}{*}{$\begin{array}{l}L G A L S 1 \\
2\end{array}$} & Forward & CAGCTGATCCCACTCТCСТC & \multirow[t]{2}{*}{176} \\
\hline & Reverse & AATGCCAGGCTCTCAGAAGA & \\
\hline \multirow{2}{*}{ GAPDH } & Forward & TTGTCTCCTGCGACTTCAAC & \multirow{2}{*}{103} \\
\hline & Reverse & TCGTACCAGGAAATGAGCTT & \\
\hline \multirow{2}{*}{$U X T$} & Forward & TGTGGCCCTTGGATATGGTT & \multirow{2}{*}{101} \\
\hline & Reverse & GGTTGTCGCTGAGCTCTGTG & \\
\hline \multirow{2}{*}{ RPS9 } & Forward & CCTCGACCAAGAGCTGAAG & \multirow{2}{*}{164} \\
\hline & Reverse & CCTCCAGACCTCACGTTTGT & \\
\hline
\end{tabular}

\section{Real-time Quantitative PCR (qPCR).}

The complete details of the procedures and conditions under which the Quantitative PCR (qPCR) was performed have been previously reported (Asiamah, Vailati-Riboni et al. 2019) . The qPCR reactions were performed in a QuantStudio $^{\text {TM }} 7$ Flex Real-Time PCR System (Applied Biosystems, CA). The geometrical mean of GAPDH, RPS9 and UXT (internal control genes) were used to normalize gene expression ( $\mathrm{Ji}$ et al., 2012). Genes were considered not expressed when the standard curve had slope $-3.50>\mathrm{y}>-3.00$ and $\mathrm{Ct}>30$. The QuantStudio $^{\mathrm{TM}} 6$ \& 7 Flex Real-Time PCR software (version 1.3 Applied Biosystems, CA) was used to analyze gene expression data.

\section{RESULTS AND DISCUSSION}

Effect of LPS and Met stimulation on galectin expression in cow neutrophils.

LGALS2 and -7 were not detected in the PMN. LGALS -1, -3, -4, -8, -9, -12 were not changed after Met supplementation in cows in the absence of LPS. LGALS4 $(\mathrm{P}=0.005)$ gene expressions increased in neutrophils in response to LPS. Results are shown in figure 1. 


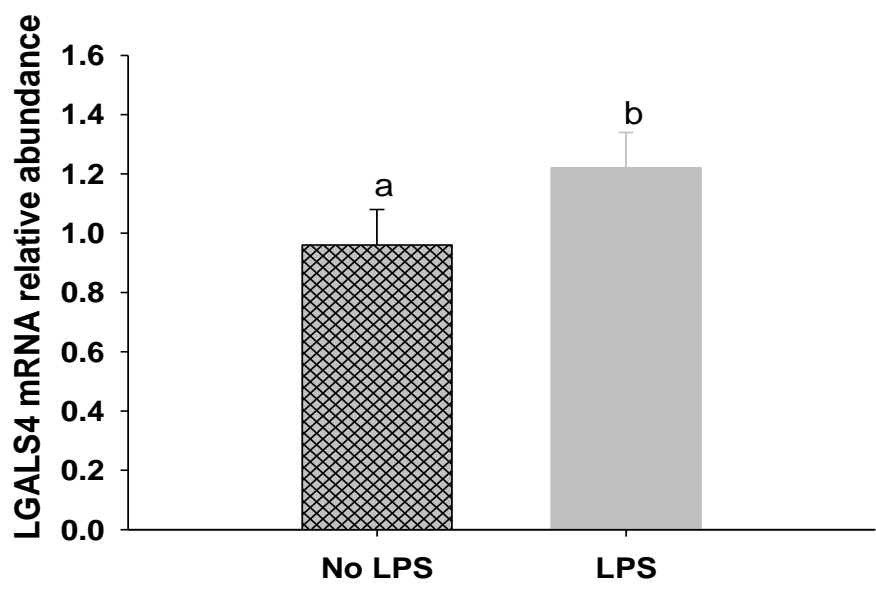

Figure 1 relative expression of LGALS4 in polymorphonuclear leukocytes $(P M N L)$ treated with LPS $(N=5)$ or No LPS $(N=5)$. Means with the same letter are not significantly different from each other (P>0.05 GLM followed by PDIFF). Error lines represent the \pm standard deviation of the mean.

Expression of LGALS12 was increased in neutrophils in response to LPS $(\mathrm{P}=0.08)$. Results are shown in figure 2.

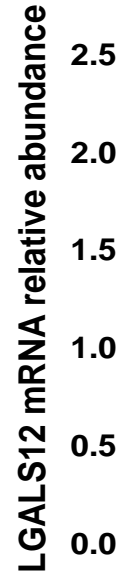

b

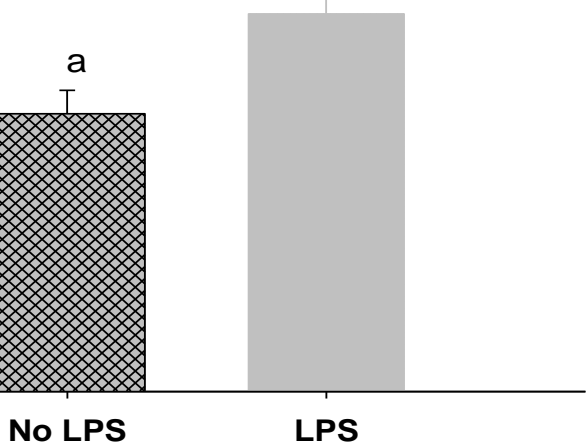

Figure 2 mRNA relative expression of LGALS12 in polymorphonuclear leukocytes $(P M N L)$ treated with LPS $(N=5)$ or No LPS $(N=5)$. Means with the same letter are not significantly different from each other $(\mathrm{P}>0.05$ GLM followed by PDIFF). Error lines represent the \pm standard deviation of the mean.

Galectin 9 expression was reduced in cow PMN treated with 2.9 Lys: Met. Results are shown in figure 3.

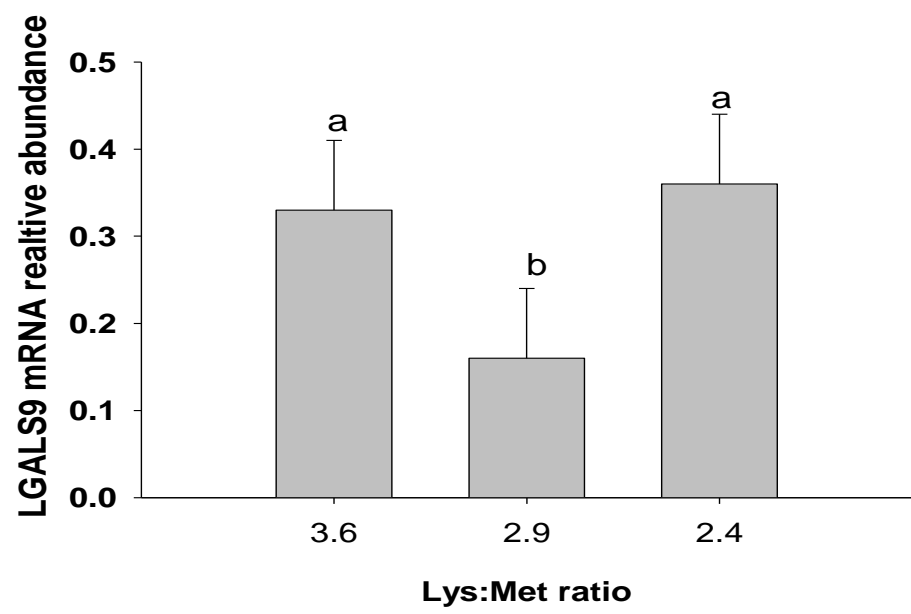

Figure 3 mRNA relative expression of LGALS9 in polymorphonuclear leukocytes $(P M N L)$ treated with 3 levels of Lysine (Lys) to Met ratios of (3.6:1, 2.9:1, or 2.4:1). Means with the same letter are not significantly different from each other ( $\mathrm{P}>0.05$ GLM followed by PDIFF). Error lines represent the \pm standard deviation of the mean.
Lys: Met ratio and LPS interaction affected LGALS8 expression. LGALS8 was increased when cow neutrophils treated with $2.9 \mathrm{~L}$ : M were challenged with LPS $(\mathrm{P}=0.0005)$. Galectin 8 in PMN treated with $3.6 \mathrm{~L}: \mathrm{M}$, however, was reduced in the presence of LPS. Galectin 8 expression did not change with or without LPS at 2.4 Lys: Met (Figure 4).

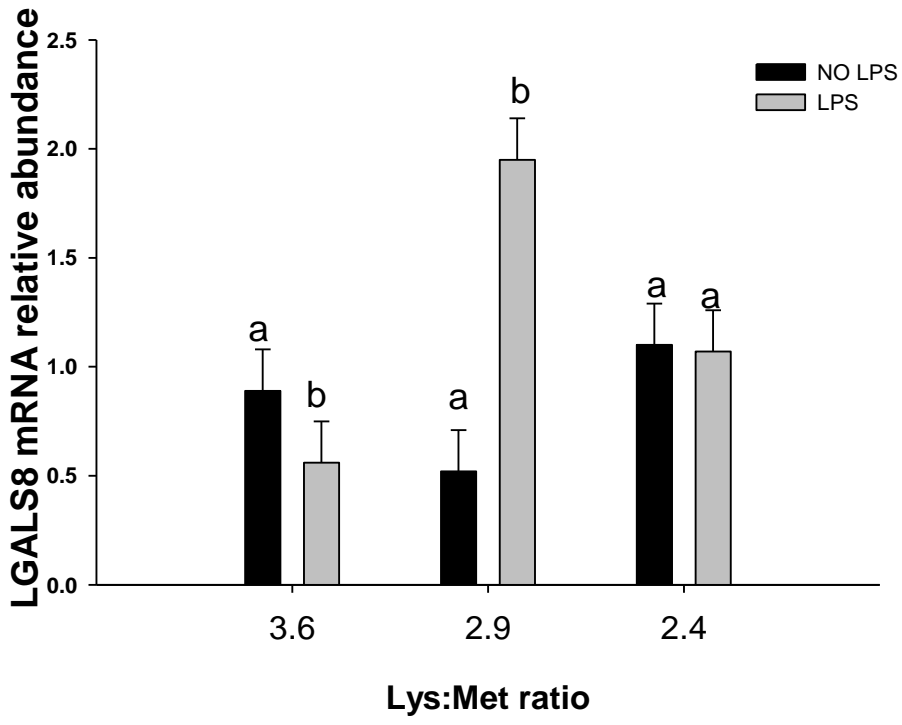

Figure $4 m R N A$ relative expression of LGALS8 in polymorphonuclear leukocytes $(P M N L)$ treated with 3 levels of Lys to Met ratios of $(3.6: 1,2.9: 1$, or 2.4:1) in the presence or absence of LPS. Means with the same letter are not significantly different from each other ( $\mathrm{P}>0.05$ GLM followed by PDIFF). Error lines represent the \pm standard deviation of the mean.

Effect of Met on LGALS expression in calf neutrophils.

LGALS 2, -7, and -9 were undetected in Calf PMN. LGALS1, -3, -4, -8, and -12 were all reduced in PMN treated with 2.4 and 2.6 Lys: Met compared to 3.6 $(\mathrm{P}=0.02)$. This is indicative that increasing methionine reduces galectin gene expression which will subsequently lead to reducing inflammation in calves. Also, increasing Choline concentration reduced galectin expression but this reduction was only significant in LGALS1 $(\mathrm{P}=0.08)$ and LGALS8 $(\mathrm{P}=0.03)$ Increasing taurine was also associated with reduced LGALS-1 $(\mathrm{P}=0.05)$ expression and also tended to reduce LGALS-12 $(\mathrm{P}=0.10)$ expression. LGALSI was reduced in PMN treated with 2.4 and 2.6 Lys: Met compared to 3.6 $(\mathrm{P}=0.02)$ (Figure 5).

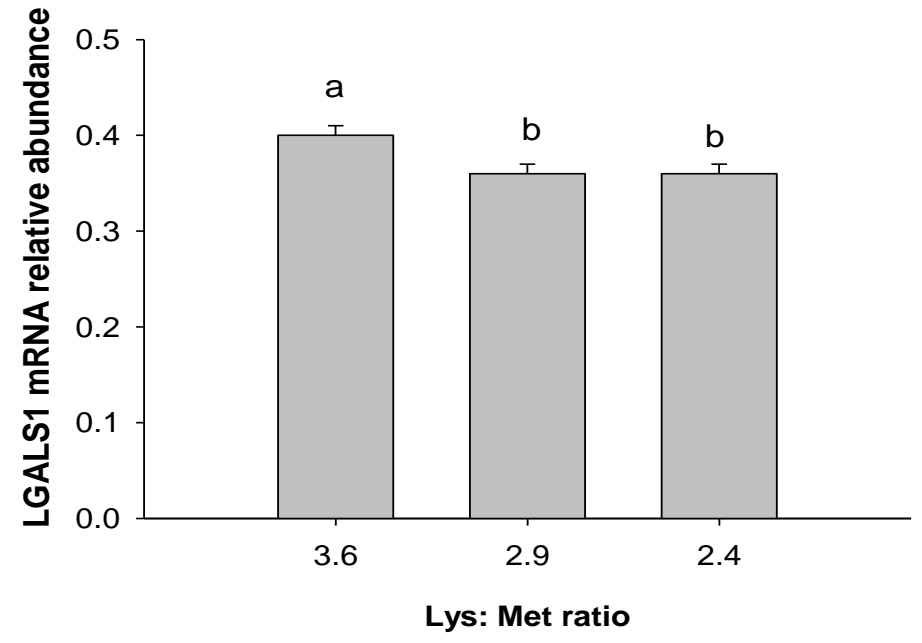

Figure 5 Effect of 3 levels of Lys: Met ratios on neutrophils relative LGALS1 mRNA abundance (standardized with 3 internal control genes) of Galectin genes in neonatal Holstein calves $(N=5)$. Means with the same letter are not significantly different from each other ( $\mathrm{P}>0.05$ GLM followed by PDIFF). Error lines represent the \pm standard deviation of the mean.

LGALS3 was reduced in PMN treated with 2.4 and 2.6 Lys: Met compared to 3.6 $(\mathrm{P}=0.02)$. Results are shown in figure 6 . 


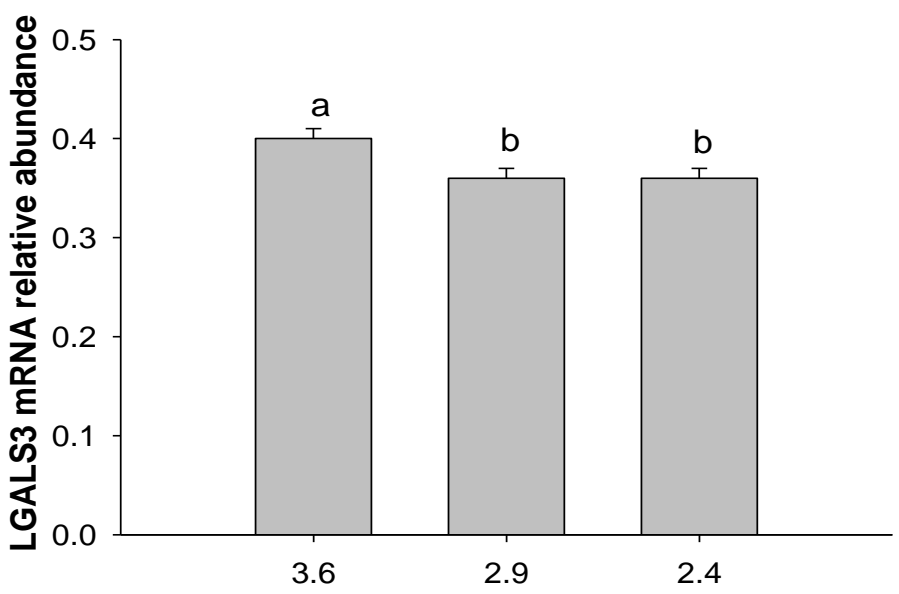

Lys: Met ratio

Figure 6 Effect of 3 levels of Lys: Met ratios on neutrophils relative galectin 3 gene (LGALS3) mRNA abundance (standardized with 3 internal control genes) of Galectin genes in neonatal Holstein calves $(N=5)$. Means with the same letter are not significantly different from each other ( $\mathrm{P}>0.05$ GLM followed by PDIFF) Error lines represent the \pm standard deviation of the mean.

LGALS4 was reduced in PMN treated with 2.4 and 2.6 Lys: Met compared to 3.6 $(\mathrm{P}=0.02)$ (Figure 7).

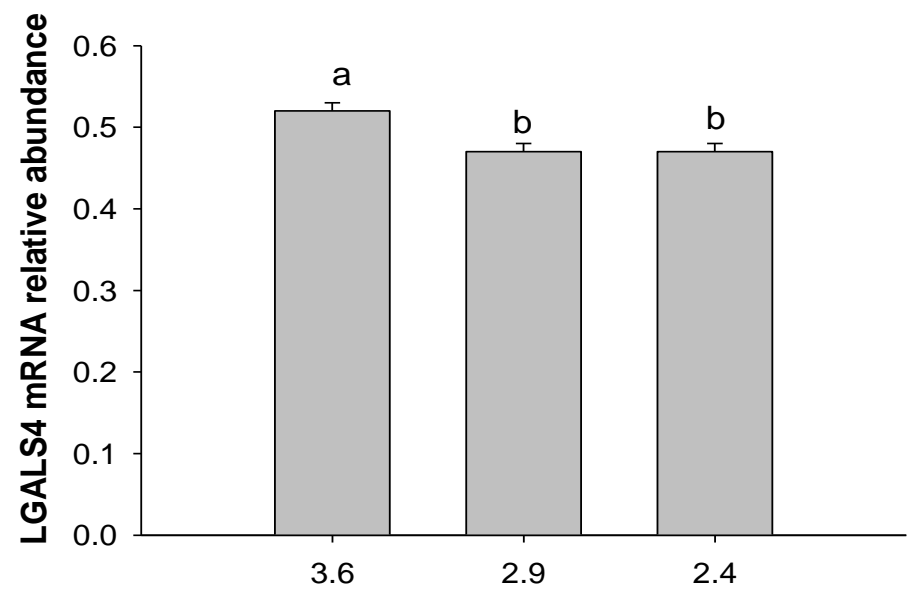

Lys: Met ratio

Figure 7 Effect of 3 levels of Lys: Met ratios on neutrophils relative LGALS4 mRNA abundance (standardized with 3 internal control genes) of Galectin genes in neonatal Holstein calves $(N=5)$. Means with the same letter are not significantly different from each other ( $>>0.05$ GLM followed by PDIFF). Error lines represent the \pm standard deviation of the mean.

LGALS8 was reduced in PMN treated with 2.4 and 2.6 Lys: Met compared to 3.6 $(\mathrm{P}=0.02)$. Results are shown in figure 8 .

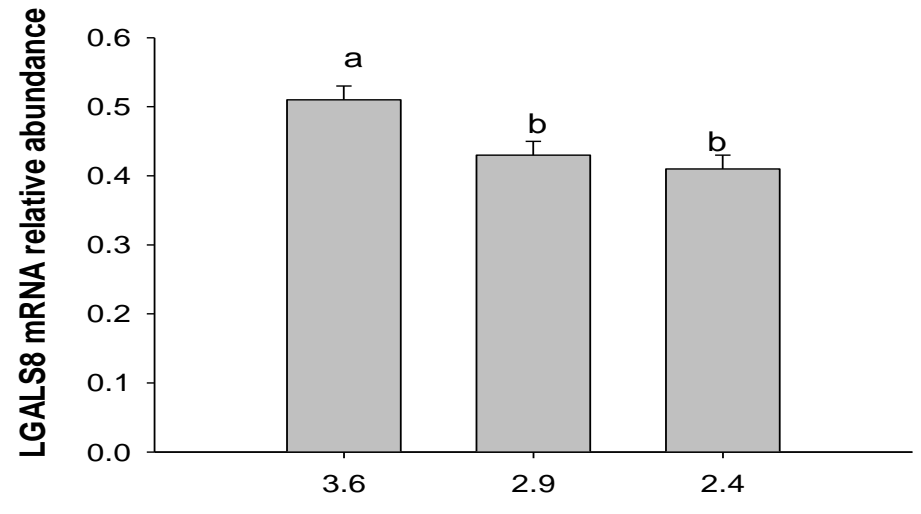

Lys: Met ratio

Figure 8 Effect of 3 levels of Lys: Met ratios on neutrophils relative LGALS8 mRNA abundance (standardized with 3 internal control genes) of Galectin genes in neonatal Holstein calves $(N=5)$. Means with the same letter are not significantly different from each other ( $\mathrm{P}>0.05$ GLM followed by PDIFF). Error lines represent the \pm standard deviation of the mean.

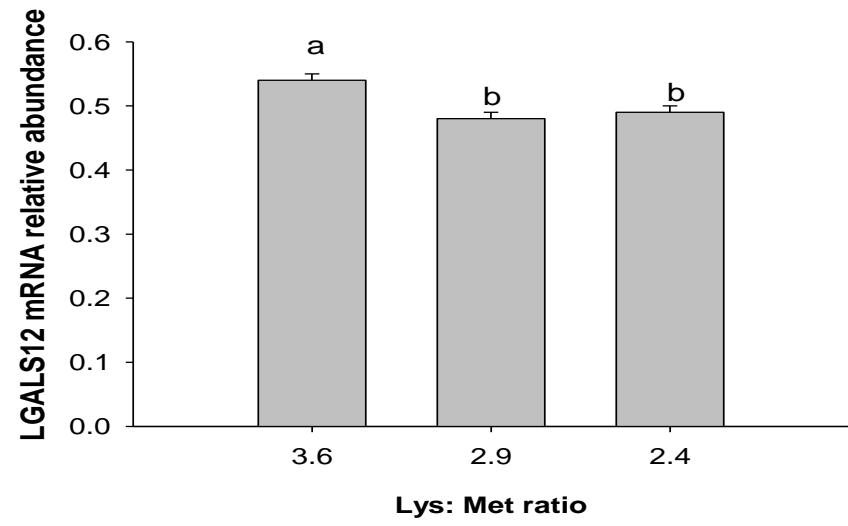

Figure 9 Effect of 3 levels of Lys: Met ratios on neutrophils relative LGALS12 mRNA abundance (standardized with 3 internal control genes) of Galectin genes in neonatal Holstein calves $(N=5)$. Means with the same letter are not significantly different from each other ( $\mathrm{P}>0.05$ GLM followed by PDIFF). Error lines represent the \pm standard deviation of the mean.

\section{Effect of taurine on LGALS expression in calf neutrophils}

Taurine concentrations $4 \mu \mathrm{g} / \mathrm{mL}$ and $8 \mu \mathrm{g} / \mathrm{mL}$ was associated with reduced LGALS1 expression $(\mathrm{P}=0.08)$. Results are shown in figure 10

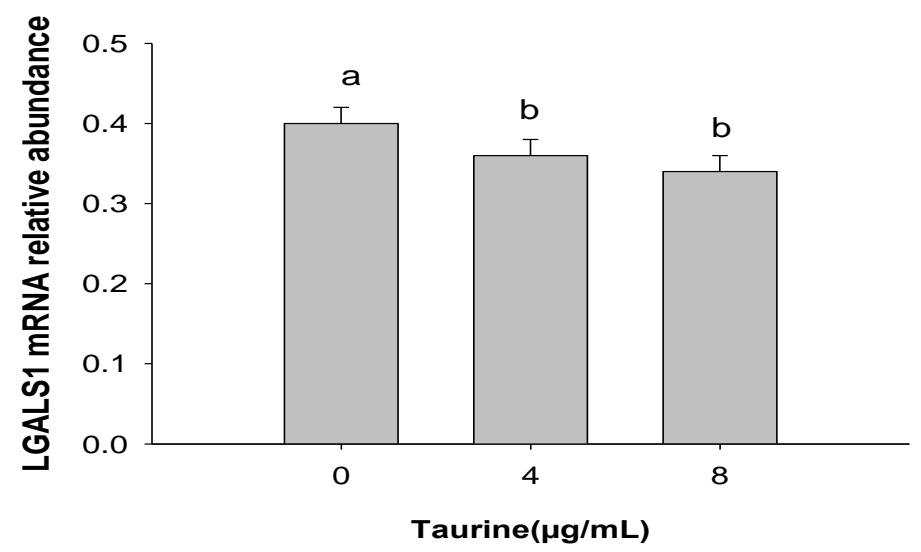

Figure 10 Effect of 3 levels of Taurine on neutrophils relative mRNA abundance (standardized with 3 internal control genes) of LGALS1 in neonatal Holstein calves $(N=5)$. Means with the same letter are not significantly different from each other $(\mathrm{P}>0.05$ GLM followed by PDIFF). Error lines represent the \pm standard deviation of the mean.

Taurine concentrations $4 \mu \mathrm{g} / \mathrm{mL}$ and $8 \mu \mathrm{g} / \mathrm{mL}$ tended to reduce LGALS12 $(\mathrm{P}=0.08)$ (Figure 50)

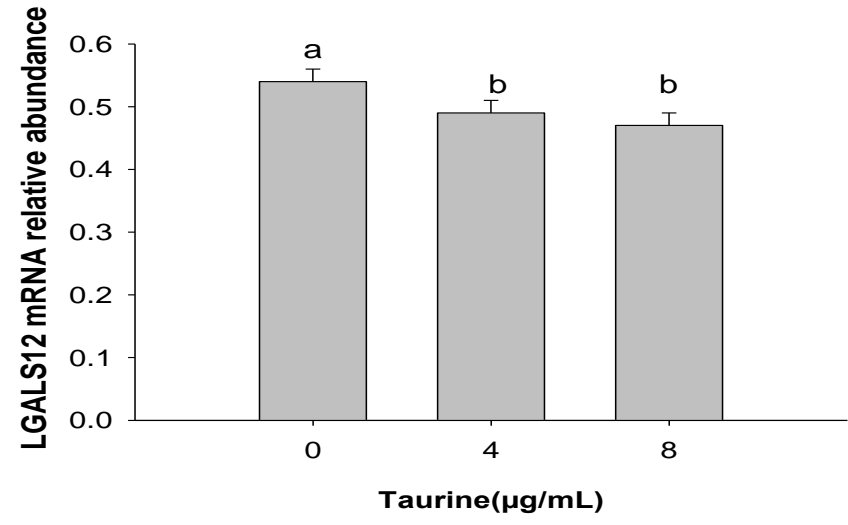

Figure 11 Effect of three levels of Taurine on relative $m R N A$ abundance (standardized with 3 internal control genes) of LGALS12 in neutrophils of neonatal Holstein calves $(N=5)$. Means with the same letter are not significantly different from each other (P>0.05 GLM followed by PDIFF). Error lines represent the \pm standard deviation of the mean. 


\section{Effect of Choline on Galectin expression in Calf neutrophils}

Choline concentrations $400 \mu \mathrm{g} / \mathrm{mL}$ and $800 \mu \mathrm{g} / \mathrm{mL}$ tended to reduce LGALS1 expression $(\mathrm{P}=0.08)$. Results are shown in figure 12 .

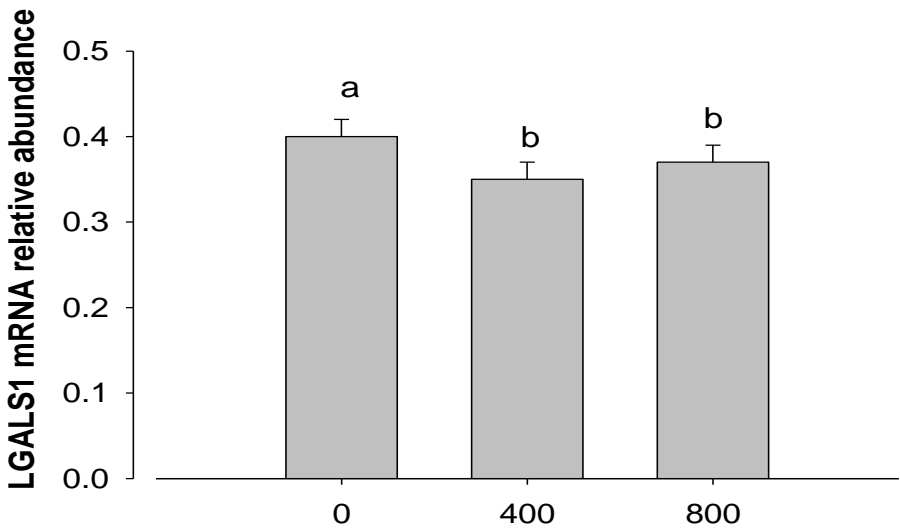

Choline ug/mL

Figure 12 Effect of three concentrations of Choline on relative mRNA abundance (standardized with 3 internal control genes) of LGALS1 in neutrophils of neonatal Holstein calves $(\mathrm{N}=5)$.

Choline concentrations $400 \mu \mathrm{g} / \mathrm{mL}$ and $800 \mu \mathrm{g} / \mathrm{mL}$ reduced LGALS8 expression $(\mathrm{P}=0.03)$. Results are shown in figure 13 .

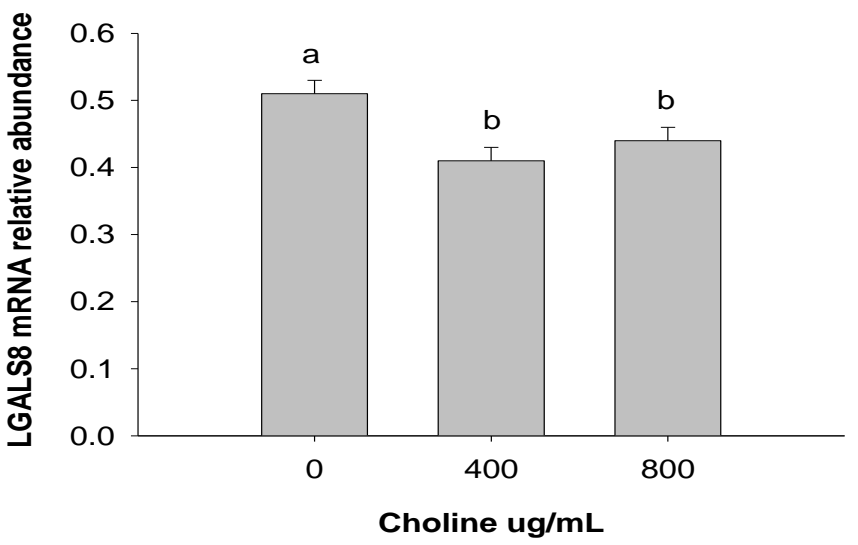

Figure 13 Effect of 3 concentrations of Choline on relative $m R N A$ abundance (standardized with 3 internal control genes) of LGALS8 in neutrophils of neonatal Holstein calves $(N=5)$. Means with the same letter are not significantly different from each other ( $\mathrm{P}>0.05$ GLM followed by PDIFF). Error lines represent the \pm standard deviation of the mean.

\section{DISCUSSION}

Maintaining host health is a vital function of the immune system, and neutrophils have a fundamental role in this process. As the primary mediators of the innate immune response, thanks to their pathogen-killing capacity, they represent the first line of defense against infections (Bannerman 2009, Kobayashi and DeLeo 2009). Met supplementation has been associated with improved phagocytotic capacity of neutrophils in cows and calves (Vailati-Riboni, Osorio et al. 2017).In this study, treatment of cow blood with different Lys: Met ratios did not change the expression of galectin genes in neutrophils. The concentration used had no impact. However, LPS increased LGALS4 and LGALS12 regardless of Met concentration. A similar effect of LPS on LGALS4 and -12 expressions was observed when whole blood was challenged with $10 \mu \mathrm{g} / \mathrm{mL}$ of LPS in a previous study (unpublished)

Previous work has implicated LGALS4 with regulating leukocyte turnover by rendering them sensitive to phagocytic recognition and removal. It has been known to induce phosphatidylserine exposure in activated neutrophils (Stowell, Karmakar et al. 2007). The current results showed that LGALS4 increased in the presence of gram-negative bacteria cell stimuli (LPS). These results suggest that LGALS4 may be activated in response to LPS recognition through the TLR-4 pathway. The results corroborate with previous research that suggests that TLR-4 could be involved in signal transduction pathway in the pathogenesis of E. coli mastitis (De Schepper, De Ketelaere et al. 2008). Furthermore, the fact that LPS tended to increase LGALS12 expression in neutrophils is noteworthy because in non-ruminants, it is a primary regulator of the early stages of adipose tissue development (Hotta, Funahashi et al. 2001). LGALS12 is associated with lipid droplets in adipocytes regulates lipolysis and insulin sensitivity. Even though they are expressed in immune cells of non-ruminants, which could suggest an immune regulatory role, the possible biologic role of LGALS12 in cow neutrophils needs to be explored.

LGALS8 has been studied to monitor and detect bacterial invasion by to binding host glycans and subsequently activating anti-bacterial autophagy (Thurston, Wandel et al. 2012). Nishi et al. (2003) reported that galectin-8 induces a firm and reversible adhesion of peripheral blood neutrophils in vitro (Nishi, Shoji et al. 2003), which suggests that they play a vital role in neutrophil migration. In this study LGALS8 transcription was also increased when cow neutrophils treated with $2.9 \mathrm{~L}$ : $\mathrm{M}$ were challenged with LPS $(\mathrm{P}<0.05)$. This means that in the presence of LPS, cows with more methionine may respond better to infection. Also, even though an increase in methionine supplementation may increase their expression, it may depend on whether there is an infection at the time of supplementation. This is evident in the results when less methionine decreases the expression of $L G A L S 8$.

Secretion of galectin-9 has been implicated with promoting migration of macrophage migration during inflammation and (Almkvist and Karlsson 2002) Galectin-9 contributes to a TH2 cytokine bias by binding to TIM-3, a membrane protein expressed on the surface of fully differentiated TH1 cells, which negatively regulates TH1 (Chen, Anderson et al. 2005, Meggyes, Miko et al 2014). In this study, 2.4 L:M reduced LGALS9 expression. The decrease in LGALS9 expression at this specific ratio indicates that Met affects LGALS9 transcription in a dose-dependent manner in neutrophils. This reduction could be attributed to the ability of Met to reduce inflammation and oxidative stress in cows (Jacometo, Zhou et al. 2016, Zhou, Bulgari et al. 2016, Vailati-Riboni, Osorio et al. 2017). Galectin-9 could play an immunomodulatory role in cows. Previous data by Abdelmegeid et al. (2017), indicated that supplementation of Met, CHO, or TAU could be beneficial for the function of neonatal calf neutrophils pro-inflammatory activity and improves their antioxidant balance. The results from this study also suggest that Met, $\mathrm{CHO}$ and TAU reduce inflammation by targeting Galectin genes involved in immune responses.

Immaturity of the neonatal immune system, especially, has been identified as the crucial cause of the high morbidity in newborn calves (Gruse, Kanitz et al. 2016). Calves are most susceptible to diseases within the first 14 days of life. Diseases that calves are most susceptible to include enteritis, diarrhea, septicemia, and pneumonia (Windeyer, Leslie et al. 2014). Furthermore, healthy calves are unable to reach the stability needed to complete the maturation of the innate immune response even by $90 \mathrm{~d}$ of age. Methionine has been previously linked with the regulation of the immune response in bovine monocytes and neutrophils (Osorio, Ji et al. 2013, Zhou, Bulgari et al. 2016). Our results revealed that LGALS1, LGALS3, LGALS4, LGALS8, and LGALS12 are reduced in neutrophils in the presence of Met, Choline, or Taurine. In non-ruminants, these galectins are all found in cells involved in immune responses have been associated neutrophils migration and pathogenicity of invading microorganism (Rabinovich, Baum et al. 2002, Rabinovich, van Kooyk et al. 2012). This decrease shows that supplementation of methyl donors to neonatal calves may lead to a reduction in inflammation. These results are consistent with the downregulation of that LGALS1, LGALS3, and LGALS4 in neutrophils of Met supplemented periparturient cows (unpublished data from previous work by our group). In the context of neonatal calves, a better basal inflammatory status (e.g., lower proinflammatory signaling) would greatly help these animals. This is because their immune system is not fully developed, especially in a period of high susceptibility to environmental pathogens.

\section{CONCLUSION}

The current data support the growing body of evidence that supplementation with Methyl donors increases immune cell antimicrobial functions. These results shed light on the immunoregulatory properties of the Galectin family in both Cow and calves and their modulation by methyl donors. This work is limited by the number of animals used in the experiment. Therefore, further studies with an increased sample size will be necessary to confirm the interplay of galectins and Met supplementation in bovine neutrophils. Furthermore, elucidation of galectin expressions and its regulation can be exploited for therapeutic purposes. We believe that the unique signatures of galectins could distinguish between homeostasis and disease in cows. The involvement of Galectins in inflammation in cows and calves need to be explored for their potential as biomarkers of important infectious diseases in the dairy industry.

Acknowledgments: The authors would like to offer their sincere gratitude to the members of the Mammalian NutriPhysioGenomics Lab (2017) at the University of Illinois Urbana Champaign. Thank you for your contributions to this study. Special thanks also go to members of the Laboratory for Animal Genomic Diversity and Animal Biotechnology (LAGenDB) at North Carolina A\&T State University for always being available to help and give their best suggestions. 


\section{REFERENCES}

ABDELMEGEID, M., VAILATI-RIBONI, M., ALHARTHI, A., BATISTEL, F. \& LOOR, J. (2017). Supplemental methionine, choline, or taurine alter in vitro gene network expression of polymorphonuclear leukocytes from neonatal Holstein calves. Journal of dairy science, 100(4), 3155-3165. doi.org/10.3168/jds.2016-12025

ADJEI-FREMAH, S., EKWEMALOR, K., ASIAMAH, E., ISMAIL, H., \& WORKU, M. (2016). Transcriptional profiling of the effect of lipopolysaccharide (LPS) pretreatment in blood from probiotics-treated dairy cows. Genom Data, 10 15-18. doi:10.1016/j.gdata.2016.08.016

ADJEI-FREMAH, S., JACKAI, L. E., SCHIMMEL, K., \& WORKU, M. (2016) Microarray analysis of the effect of Cowpea (Vigna unguiculata) phenolic extract in bovine peripheral blood. Journal of Applied Animal Research, 1-7. doi:http://dx.doi.org/10.1080/09712119.2016.1264305

ALMKVIST, J., \& KARLSSON, A. (2002). Galectins as Inflammatory Mediators. Glycoconjugate Journal, 19(7-9), 575-581. Doi:Doi 10.1023/B:Glyc.0000014088.21242.E0

ASIAMAH, E., ADJEI-FREMAH, S., EKWEMALOR, K., SORDILLO, L., \& WORKU, M. (2018). Parity and Periparturient Period Affects Galectin Gene Expression in Holstein Cow Blood. Journal of Applied Biotechnology, 6(2), 20. doi: https://doi.org/10.5296/jab.v6i2.13017

ASIAMAH, E. K., ADJEI-FREMAH, S., EKWEMALOR, K., \& WORKU, M (2016). Nystatin Modulates Genes in Immunity and Wingless Signaling Pathways in Cow Blood. Journal of Molecular Biology Research, 7(1), 1. doi:https://doi.org/10.5539/jmbr.v7n1p1

ASIAMAH, E. K. ADJEI-FREMAH, S., OSEI, B., EKWEMALOR, K. \& WORKU, M. (2016). An extract of Sericea Lespedeza modulates production of inflammatory markers in pathogen associated molecular pattern (PAMP) activated ruminant blood. Journal of Agricultural Science, 8(9), 1. doi: http://dx.doi.org/10.5539/jas.v8n9p1

ASIAMAH, E. K., EKWEMALOR, K., ADJEI-FREMAH, S., OSEI, B. NEWMAN, R., \& WORKU, M. (2019). Natural and synthetic pathogen associated molecular patterns modulate galectin expression in cow blood. Journa of Animal Science and Technology, 61(5), 245-253. doi:10.5187/jast.2019.61.5.245

ASIAMAH, E. K., VAILATI-RIBONI, M., ZHOU, Z., XU, T., LOOR, J. J., SCHIMMEL, K., \& WORKU, M. (2019). Rumen-protected methionine supplementation during the peripartal period alters the expression of galectin genes associated with inflammation in peripheral neutrophils and secretion in plasma of Holstein cows. Journal of Dairy Research, 86(4), 394-398 doi.org/10.1017/s0022029919000736

BANNERMAN, D. (2009). Pathogen-dependent induction of cytokines and other soluble inflammatory mediators during intramammary infection of dairy cows Journal of Animal Science, 87(suppl_13), 10 25. https://doi.org/10.2527/jas.2008-1187

CHEN, Z., ANDERSON, A. C., SCHUBART, A., XIONG, H., IMITOLA, J. KHOURY, S. J., . . . KUCHROO, V. K. (2005). The Tim-3 ligand galectin-9 negatively regulates T helper type 1 immunity. Nature immunology, 6(12), 1245 https://doi.org/10.1038/ni1271

COOPER, D., IQBAL, A. J., GITTENS, B. R., CERVONE, C., \& PERRETTI, M. (2012). The effect of galectins on leukocyte trafficking in inflammation: sweet or sour? Ann N Y Acad Sci, 1253(1), 181-192. doi:10.1111/j.17496632.2011.06291.x

DE SCHEPPER, S., DE KETELAERE, A., BANNERMAN, D. D., PAAPE, M. J., PEELMAN, L., \& BURVENICH, C. (2008). The toll-like receptor-4 (TLR-4) pathway and its possible role in the pathogenesis of Escherichia coli mastitis in dairy cattle. Veterinary research 39(1),

23. https://doi.org/10.1051/vetres:2007044

EKWEMALOR, K., ASIAMAH, E., OSEI, B., ISMAIL, H., \& WORKU, M (2017). Evaluation of the Effect of Probiotic Administration on Gene Expression in Goat Blood. Journal of Molecular Biology Research, 7(1), 88. https://doi.org/10.5539/jmbr.v7n1p88

GRUSE, J., KANITZ, E., WEITZEL, J. M., TUCHSCHERER, A. STEFANIAK, T., JAWOR, P., . . . HAMMON, H. M. (2016). Quercetin feeding in newborn dairy calves cannot compensate colostrum deprivation: Study on metabolic, antioxidative and inflammatory traits. PloS one, 11(1), e0146932. https://doi.org/10.1371/journal.pone.0146932

HOTTA, K., FUNAHASHI, T., MATSUKAWA, Y., TAKAHASHI, M., NISHIZAWA, H., KISHIDA, K., . . MATSUZAWA, Y. (2001). Galectin-12, an Adipose-expressed Galectin-like Molecule Possessing Apoptosis-inducing Activity. J Biol Chem, 276(36), 34089-34097. doi:10.1074/jbc.M105097200 JACOMETO, C., ZHOU, Z., LUCHINI, D., TREVISI, E., CORREA, M., \& LOOR, J. (2016). Maternal rumen-protected methionine supplementation and its effect on blood and liver biomarkers of energy metabolism, inflammation, and oxidative stress in neonatal Holstein calves. Journal of dairy science, 99(8), 6753-6763. https://doi.org/10.3168/jds.2016-11018

KAWAI, T., \& AKIRA, S. (2010). The role of pattern-recognition receptors in innate immunity: update on Toll-like receptors. Nat Immunol, 11(5), 373-384. doi:10.1038/ni.1863
KEHRLI, M. E., NONNECKE, B. J., \& ROTH, J. A. (1989). Alterations in bovine neutrophil function during the periparturient period. Am. J. Vet. Res, 50(2), 207-214

KOBAYASHI, S. D., \& DELEO, F. R. (2009). Role of neutrophils in innate immunity: a systems biology-level approach. Wiley Interdisciplinary Reviews Systems Biology and Medicine, 1(3), 309-333. https://doi.org/10.1002/wsbm.32 LI, C., BATISTEL, F., OSORIO, J. S., DRACKLEY, J. K., LUCHINI, D., \& LOOR, J. J. (2016). Peripartal rumen-protected methionine supplementation to higher energy diets elicits positive effects on blood neutrophil gene networks, performance and liver lipid content in dairy cows. J Anim Sci Biotechnol, 7(1), 18. doi:10.1186/s40104-016-0077-9

LIU, F. T., \& RABINOVICH, G. A. (2005). Galectins as modulators of tumour progression. Nature Reviews Cancer, 5(1), 29-41. doi:10.1038/nrc1527

MEGGYES, M., MIKO, E., POLGAR, B., BOGAR, B., FARKAS, B., ILLES Z., \& SZEREDAY, L. (2014). Peripheral blood TIM-3 positive NK and CD8+ T cells throughout pregnancy: TIM-3/galectin-9 interaction and its possible role during pregnancy. PloS one, 9(3), e92371. doi:10.1371/journal.pone.0092371

NISHI, N., SHOJI, H., SEKI, M., ITOH, A., MIYANAKA, H., YUUBE, K. . NAKAMURA, T. (2003). Galectin-8 modulates neutrophil function via interaction with integrin $\alpha \mathrm{M}$. Glycobiology, 13(11), 755 763. https://doi.org/10.1093/glycob/cwg102

OSORIO, J., JI, P., DRACKLEY, J., LUCHINI, D., \& LOOR, J. (2013) Supplemental Smartamine M or MetaSmart during the transition period benefits postpartal cow performance and blood neutrophil function. Journal of dairy science, 96(10), 6248-6263. https://doi.org/10.3168/jds.2013-96-12-8093

RABINOVICH, G. A., BAUM, L. G., TINARI, N., PAGANELLI, R., NATOLI, C., LIU, F. T., \& IACOBELLI, S. (2002). Galectins and their ligands: amplifiers, silencers or tuners of the inflammatory response? Trends in Immunology, 23(6), 313-320. doi:Pii S1741-4906(02)12232-9 Doi 10.1016/S1471-4906(02)02232-9 RABINOVICH, G. A., VAN KOOYK, Y., \& COBB, B. A. (2012). Glycobiology of immune responses. Ann N Y Acad Sci, 1253(1), 1-15. doi:10.1111/j.1749 6632.2012.06492.x https://doi.org/10.1111/j.1749-6632.2012.06492.x

ROSEN, H., KLEBANOFF, S. J., WANG, Y., BROT, N., HEINECKE, J. W., \& FU, X. (2009). Methionine oxidation contributes to bacterial killing by the myeloperoxidase system of neutrophils. Proceedings of the National Academy of Sciences, 106(44), 18686-18691. https://doi.org/10.1073/pnas.0909464106

SANDER, A., PIECHOTTA, M., SCHLAMBERGER, G., BOLLWEIN, H. KASKE, M., SIPKA, A., \& SCHUBERTH, H. (2011). Ex vivo phagocytic overall performance of neutrophilic granulocytes and the relation to plasma insulin-like growth factor-I concentrations in dairy cows during the transition period. Journal of dairy science, 94(4), 1762-1771. https://doi.org/10.3168/jds.2010-3275

SATO, S., ST-PIERRE, C., BHAUMIK, P., \& NIEMINEN, J. (2009). Galectins in innate immunity: dual functions of host soluble $\beta$-galactoside-binding lectins as damage-associated molecular patterns (DAMPs) and as receptors for pathogen-associated molecular patterns (PAMPs). Immunological reviews, 230(1), 172-187. https://doi.org/10.1111/j.1600-065x.2009.00790.x

SCHORN, C., JANKO, C., KRENN, V., ZHAO, Y., MUNOZ, L. E., SCHETT, G., \& HERRMANN, M. (2012). Bonding the foe - NETting neutrophils immobilize the pro-inflammatory monosodium urate crystals. Frontiers in immunology, 3, 376. doi:ARTN 37610.3389/fimmu.2012.00376

SORDILLO, L. M., CONTRERAS, G. A., \& AITKEN, S. L. (2009). Metabolic factors affecting the inflammatory response of periparturient dairy cows. Anim Health Res Rev, 10(1), 53-63. doi:10.1017/S1466252309990016

STOWELL, S. R., KARMAKAR, S., STOWELL, C. J., DIAS-BARUFFI, M., MCEVER, R. P., \& CUMMINGS, R. D. (2007). Human galectin-1,-2, and-4 induce surface exposure of phosphatidylserine in activated human neutrophils but not in activated T cells. Blood, 109(1), 219-227. https://doi.org/10.1182/blood2006-03-007153

THURSTON, T. L., WANDEL, M. P., VON MUHLINEN, N., FOEGLEIN, Á. \& RANDOW, F. (2012). Galectin-8 Targets damaged vesicles for autophagy to defend cells against bacterial invasion. Nature, 482(7385), 414 https://doi.org/10.1038/nature10744

VAILATI-RIBONI, M., OSORIO, J. S., TREVISI, E., LUCHINI, D., \& LOOR, J. J. (2017). Supplemental Smartamine M in higher-energy diets during the prepartal period improves hepatic biomarkers of health and oxidative status in Holstein cows. Journal of animal science and biotechnology, 8(1), 17 https://doi.org/10.1186/s40104-017-0147-7

WINDEYER, M., LESLIE, K., GODDEN, S., HODGINS, D., LISSEMORE, K. \& LEBLANC, S. (2014). Factors associated with morbidity, mortality, and growth of dairy heifer calves up to 3 months of age. Preventive veterinary medicine, 113(2), 231-240. https://doi.org/10.1016/j.prevetmed.2013.10.019

ZHOU, Z., BULGARI, O., VAILATI-RIBONI, M., TREVISI, E., BALLOU, M. CARDOSO, F., . . . LOOR, J. (2016). Rumen-protected methionine compared with rumen-protected choline improves immunometabolic status in dairy cows during the peripartal period. Journal of dairy science, 99(11), 8956-8969. https://doi.org/10.3168/jds.2016-10986 